\title{
Terrorism, Transit and Public Safety: Evaluating the Risks
}

Todd Litman, Victoria Transport Policy Institute Victoria, BC, CANADA

\begin{abstract}
This paper evaluates the overall safety of public transit, taking into account all risks, including recent terrorist attacks. It indicates that transit is an extremely safe mode, with total per-passenger-mile fatality rates approximately one-tenth that of automobile travel. It is important for individuals and public officials to avoid overreacting to terrorist threats in ways that increase overall danger. Transit terrorism would cause more total casualties and harm to society if individuals respond to attacks by shifting from public transit to less safe modes, or if decision makers respond by reducing support for public transit.
\end{abstract}

"The only thing we have to fear is fear itself-nameless, unreasoning, unjustified terror which paralyzes needed efforts to convert retreat into advance." - Franklin D. Roosevelt, 1932 Presidential Inaugural Address 
On July 7, 2005, terrorist bombs on London's transit system killed approximately 50 people and injured hundreds. This is not the first terrorist attack on public transit. In 1995, a religious group released sarin gas in Tokyo's subway system, killing 12 and making thousands of people sick. In recent years, bombs exploded on buses and trains in Israel, Madrid, Moscow, Paris and other cities.

Despite such events, public transit is still an extremely safe form of travel. The traffic fatality rate per passenger-kilometer is less than one-tenth that of automobile travel, as indicated in figures 1 through 3 (the analysis for these graph is in the Transit Risk spreadsheet, available from the Victoria Transport Policy Institute website at www.vtpi.org/transitrisk.xls). Even including terrorist attacks and other crimes against transit passengers, transit is far safer than private vehicle travel.

\section{Figure 1. U.K. Death Rate by Mode}

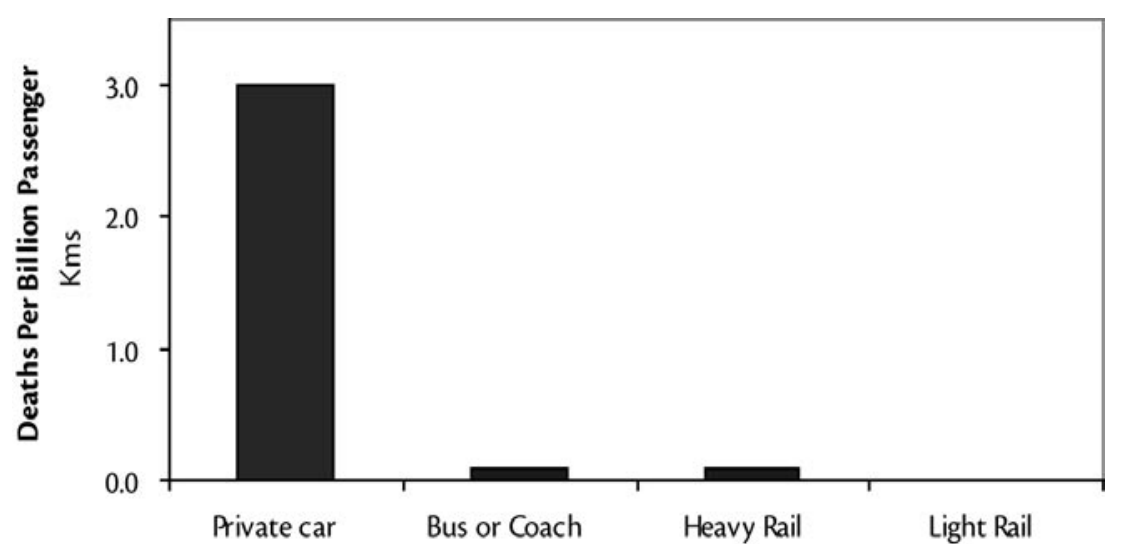

Source: (Steer Davies Gleave, 2005, Table 7.3)

Note: UK transit passengers have about one-twentieth the traffic fatality rate as automobile occupants. 


\section{Figure 2. U.S. Death Rate by Mode}

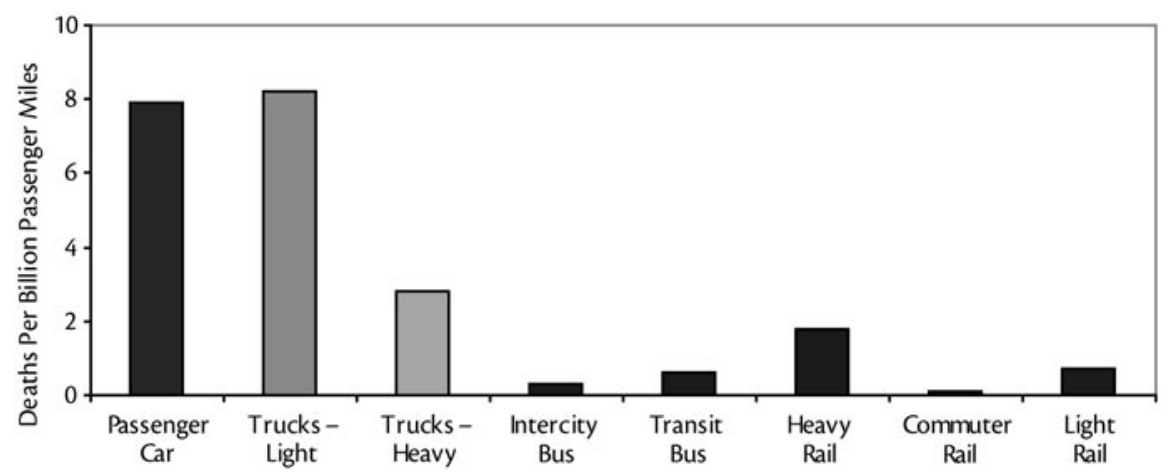

Source: (BTS, Tables 2-1 and 2-4; APTA, 2003)

Note: U.S. transit passengers have about one-tenth the traffic fatality rate as automobile occupants.

\section{Figure 3. Canadian Death Rate by Mode}

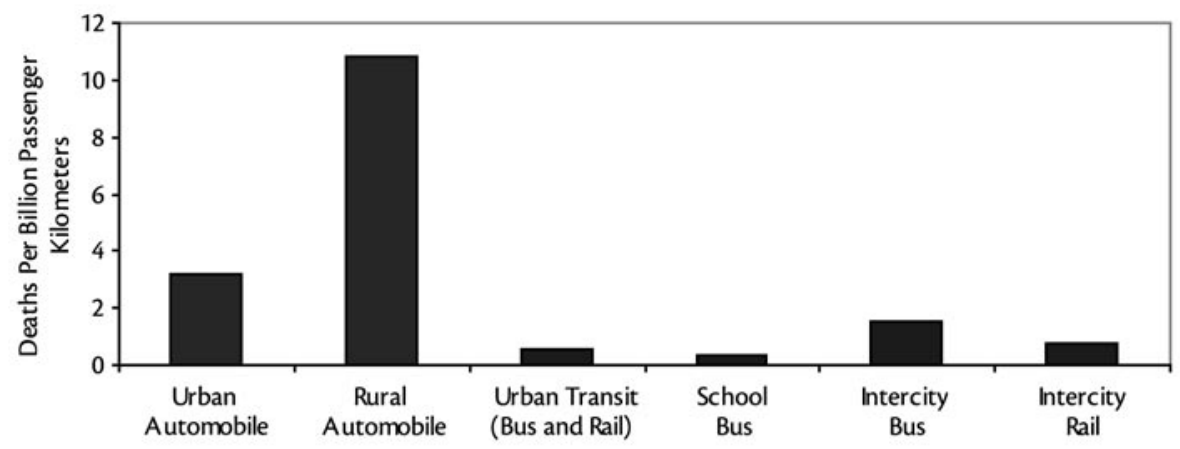

Source: (CUTA, 2000)

Note: Canadian transit passengers have about one-tenth the traffic fatality rate as automobile occupants. 
Figures 1 through 3 show only risks to transit passengers. Transit accidents also impose "external" risks on other road users (motorists, pedestrians and cyclists), but the marginal external risk of an additional transit passenger-kilometer is small, since most transit systems have excess capacity (only if additional ridership requires additional transit vehicles would external risk increase) and automobile travel imposes comparable external risks. For more discussion of marginal transit risk, see Litman 2005a and 2005b.

Shifting travel from automobile to transit and creating more transit-oriented communities increases safety for transit passengers and other road users. Total per-capita traffic fatality rates (including automobile, transit and pedestrian deaths) tend to decline as transit ridership increases in a community, as indicated in Figure 4. The decline in traffic fatalities associated with increased transit use probably results from a combination of reduced per-capita annual vehicle mileage, lower average traffic speeds in higher-density areas, and reduced driving by higher-risk motorists, such as teenagers and habitual drunk drivers, due to better alternatives to automobile travel. Transit is a significant contributor to each of these factors.

\section{Figure 4. Traffic Deaths and Transit Mileage, U.S. Cities (based on FTA data)}

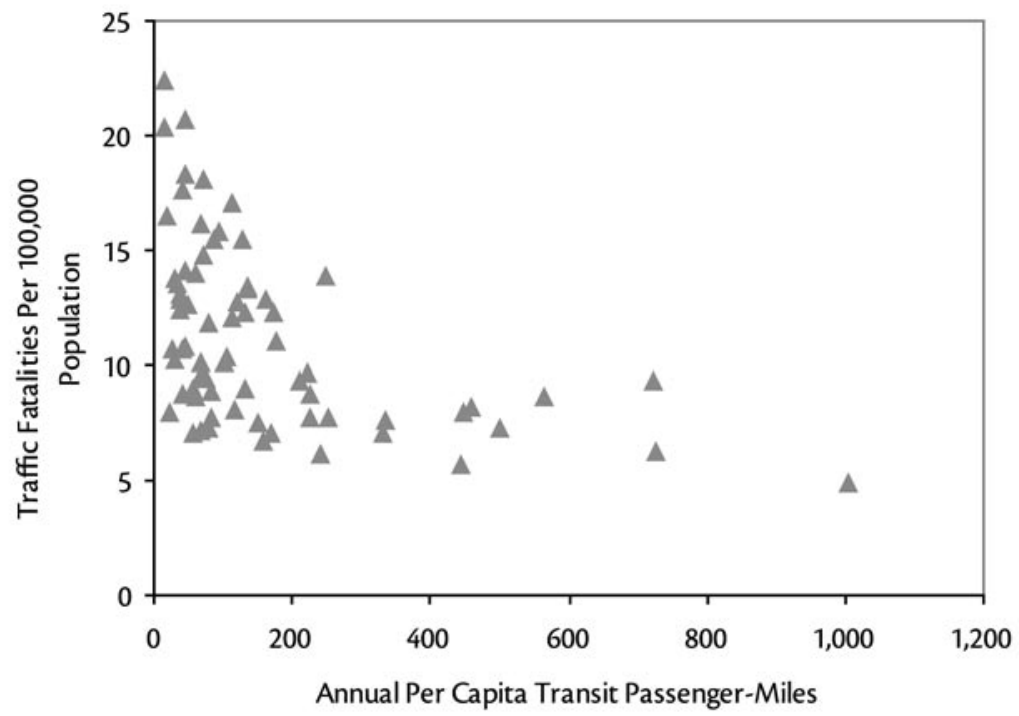


Residents of more transit-oriented urban regions experience far lower per-capita traffic fatality rates than in automobile-oriented regions, as illustrated in Figure 5. Overall, transit passengers are much safer than motorists, and residents of transitoriented communities are safer than residents of automobile-oriented communities, even taking into account risks from murder and terrorism (Lucy 2002).

\section{Figure 5. Annual Per Capita Traffic Deaths}

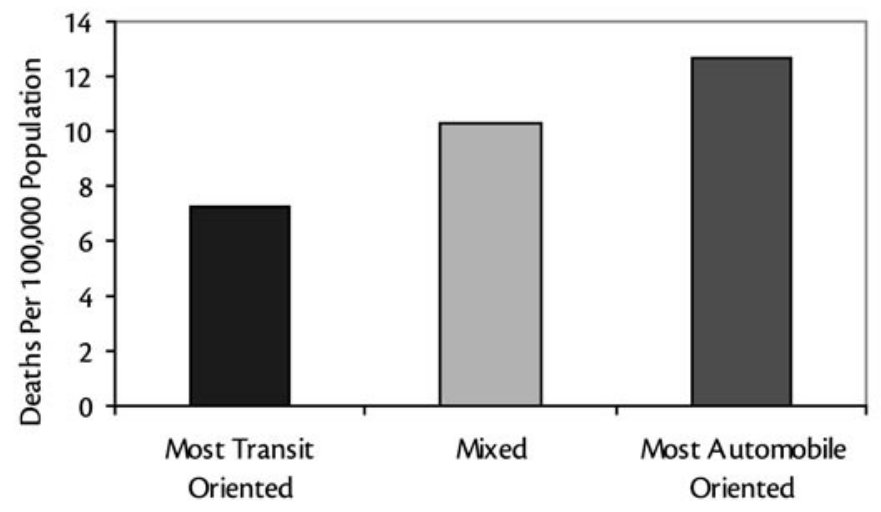

Source: Litman, 2004

Note: Transit-oriented urban regions have significantly lower per-capita traffic fatality rates than more automobile-oriented cities. "Most Transit Oriented" are the 10 U.S. cities with the highest per-capita annual transit mileage (333 to 1,004 annual transit passenger miles). "Mixed" are the next 20 cities ranked by transit mileage (118 to 254 annual transit passenger miles). "Most Automobile Oriented" are the remainder (15 to 114 annual transit passenger-miles).

International data also indicate that per-capita traffic fatalities decline with increased transit ridership, as indicated in Figure 6. 


\section{Figure 6. International Traffic Deaths}

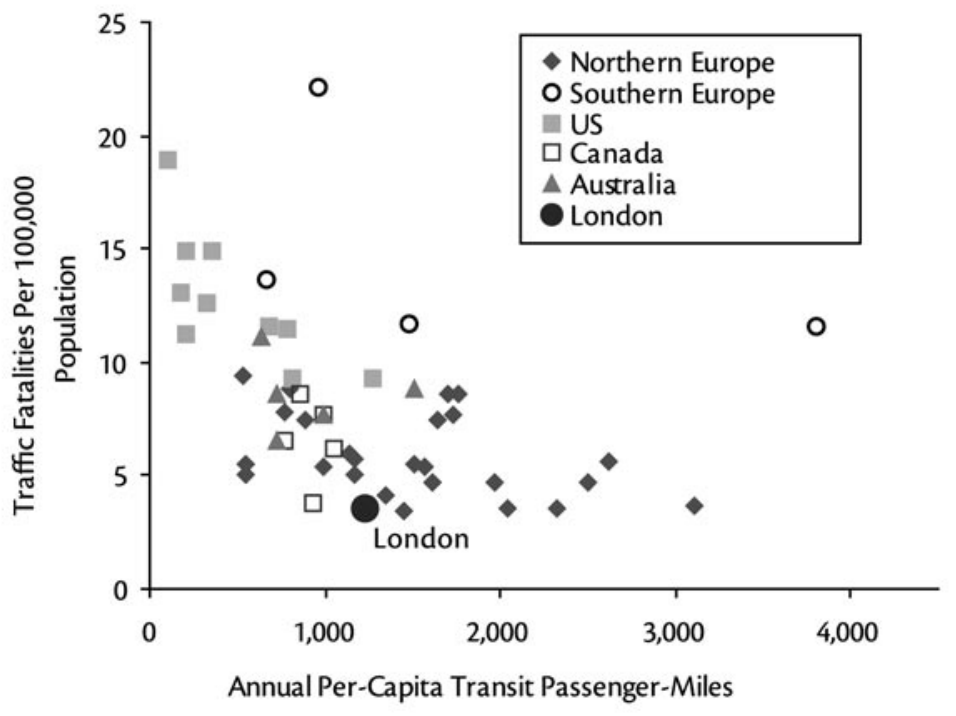

Source: (Kenworthy and Laube, 2000)

Annual road and rail traffic deaths total 286 in the London region, about 3,500 in the U.K., and more than 43,000 in the U.S., of which only a small portion involve public transit passengers, as summarized in Table 1.

\section{Table 1. Traffic Fatality Data Summary}

\begin{tabular}{l|r|r|r}
\cline { 2 - 4 } & \multicolumn{1}{c|}{ London } & \multicolumn{1}{c|}{ U.K. } & \multicolumn{1}{c}{ U.S. } \\
\hline $\begin{array}{l}\text { Automobile/motorcycle passenger } \\
\text { deaths }\end{array}$ & $143(50.0 \%)$ & $2,574(73.6 \%)$ & $37,192(87.2 \%)$ \\
\hline Bus transit passenger deaths & $7(2.4 \%)$ & $11(0.3 \%)$ & $64(0.1 \%)$ \\
\hline Rail transit passenger deaths & $9(3.1 \%)$ & $12(0.3 \%)$ & $45(0.1 \%)$ \\
\hline Rail passenger deaths & $-(0.0 \%)$ & $20(0.6 \%)$ & $3(0.0 \%)$ \\
\hline Non-motorized deaths & $127(44.4 \%)$ & $882(25.2 \%)$ & $5,371(12.6 \%)$ \\
\hline \multicolumn{1}{r|}{ Total Deaths } & $286(100 \%)$ & $3,499(100 \%)$ & $42,675(100 \%)$ \\
\hline
\end{tabular}


Of the 286 transportation fatalities in London, only 5.6 percent involved public transport passengers, although public transport provides 24.2 percent of total passenger trips and 20.1 percent of passenger-kilometers, as indicated in Table 2.

\section{Table 2. London Area 2003 Travel and Fatalities By Mode}

\begin{tabular}{|c|c|c|c|}
\hline & Million Trips & Million Kms & User Deaths \\
\hline Bus & $1,430(14.3 \%)$ & $5,128(8.1 \%)$ & $7(2.4 \%)$ \\
\hline Underground & $953(9.5 \%)$ & $7,451(11.7 \%)$ & $9(3.1 \%)$ \\
\hline Docklands (DLR) & $41(0.4 \%)$ & $207(0.3 \%)$ & $0(0.0 \%)$ \\
\hline Car/motorcycle & $4,015(40.0 \%)$ & $\begin{array}{r}46,976 \\
(73.8 \%)\end{array}$ & $143(50 \%)$ \\
\hline Taxi & $99(1.0 \%)$ & $503(0.8 \%)$ & $0(0.0 \%)$ \\
\hline Walk & $3,366(33.5 \%)$ & $2,693(4.2 \%)$ & $\begin{array}{r}107 \\
(37.4 \%)\end{array}$ \\
\hline Bicycle & $131(1.3 \%)$ & $693(1.1 \%)$ & $20(7.0 \%)$ \\
\hline $\begin{array}{l}\text { Total transit (bus, underground, } \\
\text { DLR) }\end{array}$ & $2,424(24.2 \%)$ & $\begin{array}{r}12,785 \\
(20.1 \%)\end{array}$ & $16(5.6 \%)$ \\
\hline $\begin{array}{l}\text { Total automobile (car, motorcycle, } \\
\text { taxi) }\end{array}$ & $4,114(41.0 \%)$ & $\begin{array}{r}47,478 \\
(74.6 \%)\end{array}$ & $\begin{array}{r}143 \\
(50.0 \%)\end{array}$ \\
\hline $\begin{array}{l}\text { Total non-motorized modes (walk, } \\
\text { bicycle) }\end{array}$ & $3,497(34.8 \%)$ & $3,385(5.3 \%)$ & $\begin{array}{r}127 \\
(44.4 \%)\end{array}$ \\
\hline Totals & $\begin{array}{r}10,034 \\
(100 \%)\end{array}$ & $\begin{array}{l}63,649 \\
(100 \%)\end{array}$ & $\begin{array}{r}286 \\
(100 \%)\end{array}$ \\
\hline
\end{tabular}

Source: (TfL, 2004)

If public transit had the same fatality rate per passenger-mile as automobile travel, there would have been 104 more deaths in London, 300 in the U.K., and 148 in the U.S. in 2003 (calculations in www.vtpi.org/transitrisk.x/s). These are lower-bound estimates because they assume that each transit passenger-mile replaces just one automobile passenger-mile. However, when people shift from driving to transit, they tend to reduce their annual mileage, because transit users often choose closer destinations and avoid unnecessary trips. As public transit ridership increases in a community, per-capita vehicle ownership tends to decline, and land use patterns 
become more accessible and walkable, further reducing vehicle mileage. Described differently, as a community becomes more automobile-oriented, destinations tend to disperse, due, in part, to the need to dedicate more land to roads and parking facilities, causing people to travel more to maintain a given level of accessibility.

As a result, each transit passenger-mile often replaces several automobile vehiclemiles (Litman 2004). This is one of the reasons that increased per capita transit ridership provides such large reduction in per-capita traffic fatality rates, as indicated earlier. If residents of the "Transit Oriented" regions described earlier in Figure 5 had the same traffic fatality rate as the "Automobile-Oriented," there would be about 2,500 additional traffic fatalities in the U.S. (calculations in www. vtpi.org/transitrisk.xls).

These safety benefits of transit are much larger than deaths and injuries caused by recent terrorist attacks. In addition, public transit provides other health benefits, by reducing air pollution and increasing physical exercise, since most transit trips involve walking or cycling links. Although these health benefits are difficult to quantify, they appear to be large, indicating far greater total health benefits from transit and, therefore, much larger disbenefits when people shift from transit to driving (Litman 2003). Travelers would increase their total risk if they shift from transit to driving in response to terrorist threats.

Transit risks tend to receive more attention than automobile risks. Because they are rare, incidents that kill or injure a few transit passengers often receive national or international media attention, while automobile crashes that kill a few people are so common they are considered local news, and injury accidents often receive no media coverage at all. For example, in 1995 the death of three passengers in a Toronto subway crash was widely reported in British Columbia. The same week, the death of four teenagers in a car crash was a local news story without media coverage in Toronto. This suggests that a transit passenger death receives about 100 times as much media coverage as an automobile passenger death.

Traffic accidents actually represents a much greater risk than terrorism (Adams 2005):

- On an average day, 9 people die and over 800 are injured in British road accidents. The July 7 London terrorist deaths represent about six days of normal traffic fatalities. 
- The 191 people killed March 11, 2004, by Madrid bombers were equivalent to about 12 or 13 days of normal traffic deaths in Spain.

- During the 25 worst years of sectarian violence in Northern Ireland, twice as many people died there in road accidents as were killed by terrorists.

- In Israel, the annual road traffic death toll has been two or three times higher than civilian deaths by Palestinian terrorists during the violent years of 2000 through 2003.

- The September 11, 2001, terrorist attacks killed about the same number of people as a typical month of U.S. traffic accidents. According to official reports, terrorists killed 25 Americans worldwide in 2002, 23 in 2003, and none in 2004, while about 42,000 Americans died in traffic accidents each of these years.

There are several reasons that people react particularly strongly to terrorist attacks (Adams 2005). Such attacks are designed to be highly visible, producing intense media coverage. The fact that the harm they cause is intentional rather than accidental makes them particularly tragic and frustrating. And they raise fears that such attacks may become more frequent or severe, so risks may increase in the future. For these reasons, it is not surprising that transit terrorism tends to instill more fear than other risks that are actually much greater overall. That is exactly what terrorists intend.

This is not to suggest that transit terrorism risks are insignificant and should be ignored. On the contrary, transit terrorism is a serious threat that harms people both directly, through injury and property damage, and indirectly by creating fear and confusion. Strong action is justified to protect transit users' safety and sense of security.

Society should work aggressively to prevent terrorists attacks, respond to incidents, and bring terrorists to justice. Transportation professionals, and transit operators and users should be cautious and vigilant (for more discussion of strategies for increasing transit security, see the "Address Security Concerns" chapter of the VTPI Online TDM Encyclopedia at www.vtpi.org/tdm/tdm37.htm). Many transport organizations are currently working to increase transit security (APTA, 2005; FTA, 2005; MTI, 2005; Loukaitou-Sideris, 2005). Much more can be done. The federal government spent $\$ 22$ billion-more than $\$ 9$ per passenger-on air transportation security after September 11, 2001 attacks, but less than 1c per passenger to increase railway and subway security (Howitt and Makler 2005). 
But it is important for individuals and public officials to take all risks into account and avoid overreacting to transit terrorism risks in ways that increase overall danger. Transit terrorism would cause greater total casualties and harm to society if individual travelers respond to exaggerated fears by shifting from public transit to less safe modes, or if decision makers respond by reducing support for public transit.

Such shifts have occurred. Analysis by Gigerenzer (2004) and Sivak and Flannagan (2004) indicate that in the three months after the September 11, 2001, terrorist attacks, shifts from air to automobile travel caused several hundred additional roadway traffic fatalities. Since air travel is safer per mile than driving, particularly on rural roads, total travel deaths increased. Had these trends continued for more than a year, the additional deaths would have exceeded the September 11 terrorist deaths. Because of actions by governments and the airline industry to increase air travel security, these travel shifts have been reduced, reducing excess traffic deaths.

After a high-profile transit accident or attack, news reporters sometimes stick a microphone in front of transit riders and ask, "How can you possibly continue using transit after what just happened?" with the implication that riding transit is dangerous and foolish. This reflects the myopic tendency of news media to consider just one issue at a time. But people and policy makers must balance many factors, including overall safety, efficiency, and affordability. It would be foolish for travelers to reduce their transit travel in response to a terrorist attack, despite the fact that transit is an extremely safe mode of travel and provides other benefits to users and society.

When terrorist attacks occur, responsible leaders rightfully recommend that people return to their normal habits, including public transit travel. Cities repair their public transit systems and people use them, both for practical reasons and to show they are not intimidated by terrorism. 


\section{References}

Adams, John. 2005. What kills you matters, not numbers, The Social Affairs Unit (www.socialaffairsunit.org.uk/blog/archives/000512.php).

APTA. 2005. Public transit and security issues website (www.apta.com/services/ security).

APTA. Various years. Public transportation national summaries and trends statistics. American Public Transit Association (www.apta.com/research/stats).

BTS. Various years. National Transportation Statistics, Bureau of Transportation Statistics (www.bts.gov).

Chan, Sewell. 2005. Easing anxiety on mass transit. New York Times (www.nytimes. com), July 17, 2005.

CUTA. 2000. Transit's safety and security record. STRP S3, Canadian Urban Transit Association (www.cutaactu.ca).

DfT. 2004. Transport statistics for Great Britain. Department for Transport (www. dft.gov.uk/stellent/groups/dft_transstats/documents/page/dft_transstats_ 031999.hcsp).

FTA. 2005. Transit security website. Federal Transit Administration (http://transitsafety.volpe.dot.gov/Security/Default.asp).

Gigerenzer, G. 2004. Dread risk, September 11, and fatal traffic accidents. Psychological Science, Vol. 15, pp. $286-287$.

Howitt, Arnold, and Jonathan Makler. 2005. On the ground: Protecting America's roads and transit against terrorism. Brookings Institute (www.brookings.edu/ metro/pubs/20050426_howitt.htm).

Kenworthy, Jeffrey, and Felix Laube. 2000. Millennium cities database for sustainable transport. Institute for Sustainability and Technology Policy, distributed by the International Union of Public Transport (www.uitp.com).

Leahy, Stephen. 2005. Washington cuts security funds for public transport. Inter Press Service (http://ipsnews.net/news.asp?idnews=29575), 20 July 2005.

Litman, Todd. 2003. Integrating public health objectives in transportation decision-making. American Journal of Health Promotion, Vol. 18, No. 1, Sept./Oct. 2003, pp. 103-108, available at VTPI (www.vtpi.org). 
Litman, Todd. 2004. Rail transit in America. VTPI (www.vtpi.org).

Litman, Todd. 2005a. Evaluating public transit benefits and costs. VTPI (www.vtpi. org).

Litman, Todd. 2005b. Safe travels: Evaluating mobility management safety impacts. Victoria Transport Policy Institute (www.vtpi.org).

Loukaitou-Sideris, Anastasia, 2005. Terror on mass transit. School of Public Policy and Social Research, UCLA. (www.international.ucla.edu/article. asp?parentid=8849).

Lucy, William. 2002. Danger in exurbia: outer suburbs more dangerous than cities. University of Virginia (www.virginia.edu).

National Transportation Security Center, Mineta Transportation Institute (http:// transweb.sjsu.edu/transitsecurity.htm). Provides various transportation security publications and other information resources.

Sivak, Michael, and Michael J. Flannagan. 2004. Consequences for road traffic fatalities of the reduction in flying following September 11, 2001. Transportation Research Part F: Traffic Psychology and Behaviour, Volume 7, Issues 4-5 (www. sciencedirect.com/science/article/B6VN8-4DS736P-5/2/3bfded271f0caf8e6bd07 ad120603595), July-September 2004, pp 301-305.

Steer Davies Gleave. 2005. What light rail can do for cities: A review of the evidence. UK Passenger Transport Executive Committee (www.pteg.net).

TfL. 2004. London Travel Report 2004. Transport for London (www.tfl.gov.uk/tfl/ reports_library_stats.shtml).

Transportation Research Board. Transportation system security website (www4. trb.org/trb/homepage.nsf/web/security),

USDOT. 2005. Effects of catastrophic events on transportation system management and operations: New York City - September 11. U.S. Department of Transportation (www.itsdocs.fhwa.dot.gov//JPODOCS/REPTS_te/14129.htm).

Victoria Transport Policy Institute. Transit Risk. www.vtpi.org/transitrisk.xls. 


\section{About the Author}

TODD LITMAN (info@vtpi.org) is founder and executive director of the Victoria Transport Policy Institute, an independent research organization dedicated to developing innovative solutions to transport problems. His work helps to expand the range of impacts and options considered in transportation decision-making, improve evaluation techniques, and make specialized technical concepts accessible to a larger audience. His research is used worldwide in transport planning and policy analysis.

Mr. Litman is author of the Online TDM Encyclopedia, a comprehensive Internet resource for identifying and evaluating mobility management strategies. He has worked on numerous studies that evaluate the costs and benefits of various transportation services and activities. He authored Transportation Cost and Benefit Analysis: Techniques, Estimates and Implications, a comprehensive study of transport impacts, which provides cost and benefit information in an easy-to-apply format. 